\title{
New study on the neuromuscular dystrophy rehabilitation program
}

\author{
Roxana_MICLAUS ${ }^{1}$, Nadinne ROMAN ${ }^{2}$
}

\begin{abstract}
Neuromuscular dystrophy is a progressive disease, interesting skeletal muscles by progressive weakness and loss of voluntary motor function.

Material and Methods: A prospective study was developed on 16 patients with progressive neuromuscular dystrophy, over a three months period. The initial and final assessment included muscle manual testing, range of motion and, for the functional outcomes, the Vigos Scale, Barthel Scale, Activity of Daily Living (ADL) Score, and Muscular Dystrophy Scale were used. The physiotherapy program was developed on four stages and a guiding protocol was used for the individualization of the physical therapy program. The statistical analysis was performed in Microsoft Excel, using a Paired samples T-test.

Results: Statistical significant results were obtained within all assessment tools. Muscle strength and ADL capacity improved, with the highest increases in patients with low levels of disability.

Conclusion: The main results suggest that individualized physiotherapy can slow the progressivity of the disorder and improve the quality of life, especially when started at an earlier stage of the disease.
\end{abstract}

Key words: physical therapy, neuromuscular dystrophy, functional recovery

\section{Rezumat}

Distrofia neuromusculară este o boală progresivă, mușchii scheletici fiind afectați de slăbiciune progresivă și pierderea fun cției motorii voluntare.

Material și metode: A fost realizat un studiu prospectiv pe 16 pacienți cu distrofie neuromusculară progresivă, pe o perioadă de trei luni. Evaluarea inițială și finală au inclus testarea manuală a mușchilor, amplitudinea de mișcare și pentru rezultate funcționale, s-au utilizat Scala Vigos, Scala Barthel, Scorul ADL și Scala de Distrofie Musculară. Programul de fizioterapie a fost dezvoltat pe patru etape și a fost utilizat un protocol de ghidare pentru individualizarea programului de kinetoterapie. Analiza statistică a fost realizată în Microsoft Excel, folosind un test T pe perechi.

Rezultate: Au fost obținute rezultate semnificative statistice în cadrul tuturor instrumentelor de evaluare. Forța musculară și capacitatea de realizare a activităților zilnice s-au îmbunătățit, cu cele mai mari creșteri înregistrate la pacienții cu un nivel scăzut de handicap.

Concluzie: Rezultatele principale sugerează că fizioterapia individualizată poate încetini progresivitatea tulburării și poate îmbunătăți calitatea vieții, mai ales atunci când este inițiată într-un stadiu incipient al bolii.

Cuvinte cheie: fizioterapie, distrofie neuromusculară, recuperare funcțională

\footnotetext{
${ }^{1}$ Associate Professor, MD, PhD, Faculty of Medicine, Transilvania University of Brasov, Romania

${ }^{2}$ Assistant Professor, Physiotherapist, PhD student, Faculty of Medicine, Transilvania University of Brasov, Romania, email:

nadinneroman@gmail.com
} 


\section{Introduction}

Neuromuscular dystrophy is a group of hereditary rare diseases, characterized by the progressive deterioration of the body muscles, resulting in muscle weakness and disability [1].

Muscular dystrophy is manifested by the progressive weakening of the muscles, especially the skeletal muscles. As the disease progresses, necrotic muscle fibres are replaced by connective and adipose tissue. Myocardial damage occurs in some forms of the disease and also affects smooth muscles. Each of its forms differs in terms of symptoms onset of, the disease, and hereditary transmission mode [2].

\section{Types of progressive neuromuscular dystrophy.}

The prevalence of muscle dystrophies is generally low, considering that the numbers which were reported range between 0.5 and 18.1/100 000 individuals for myotonic dystrophy, between 1.7 and 4.2 for Duchenne, and between 3.2 and 4.6/100 000 for facioscapulohumeral muscular dystrophy. These types were most commonly encountered, out of a total of thirty disorders [3]. Therefore, we studied only four types of neuromuscular dystrophies, due to the low prevalence of these types of diseases:

A) Duchenne muscular dystrophy is a genetically Xlinked transmitted disease, recessive, childhoodonset occurs between 1 and 5 years [4].

B) Facioscapulohumeral muscular dystrophy is an autosomal dominant disease and can occur in both genders. [1] The onset of the disease occurs in 6-12year-olds up to the age of 30 , and signs of the disease appear before 20 years of age in $95 \%$ of cases. The disease starts insidiously, with a slow evolution $[5,6]$

C) Limb-girdle muscular dystrophy, is a genetically determined disease that is characterized by progressive muscular atrophy, mainly affecting the shoulder girdle muscles, those closest to the body (proximal muscles), specifically the muscles of the shoulders, upper arms, pelvic area, and thighs. The disease begins at the age of 10-15 years, or even after $20[7,8,9]$

D) The main associated pathologies with myotonic dystrophy evolution, besides muscle weakness, are affecting other organs and systems. Disorders related to cataracts, cardiac conduction, endocrine vegetative syndrome, and moderate mental retardation are notified. The age of onset of the decline in muscle strength varies within the same family, most patients become symptomatic at the end of the second decade or the beginning of the third decade of life $[3,10,11]$.

\section{Material and methods}

The study was conducted on a group of sixteen patients, having their main diagnosis of progressive muscular dystrophy in the Hospital of Neurology and Psychiatry Brașov.

Inclusion criteria targeted patients with the most common types of muscular dystrophy (Myotonic, Facioscapulohumeral, Duchenne, Limb-Girdle). Exclusion criteria were assigned to patients completely immobilized in bed and to patients who had missed physiotherapy in the last five years. The patients' characteristics are found in Table I.

Table I. Group study characteristics and interventions

\begin{tabular}{|c|c|}
\hline $\begin{array}{l}\text { Types of } \\
\text { dystrophy }\end{array}$ & $\begin{array}{llll}\text { Myoto } & \text { Fascio } & \text { Duchenne } & \text { Limb } \\
\text { nic } & \text { Scapulo } & & \text { Girdle } \\
& \text { humeral } & & \\
\end{array}$ \\
\hline Cases & 8 \\
\hline Assessment & $\begin{array}{l}\text { Manual Muscle Testing, Range of } \\
\text { Motion, Muscular Dystrophy Rating } \\
\text { Scale, Broke Scale, Vignos Scale, Barthel } \\
\text { Scale, and ADL Score }\end{array}$ \\
\hline Intervention & $\begin{array}{l}\text { Individualised physiotherapy exercise } \\
\text { program based on protocol }\end{array}$ \\
\hline Minutes/day & 60 \\
\hline First 2 weeks & Daily \\
\hline Length & 3 Months \\
\hline Mean age & 41.25 \\
\hline
\end{tabular}

Our physical rehabilitation program aimed to:

(1) Maintain and improve muscle strength and force for both the scapular and pelvic girdle, lower and upper extremities; (2) Re-educate control, coordination based on the kinematic chains in the limbs; (3) Re-education of stability and balance; (4) Re-education of the respiratory capacity; (5) Maintain the exercise capacity for reaching ADLs, transfers and walking for short periods of time; (6) Prolongation of the ability to walk [9].

The physical rehabilitation program was divided into several stages.

A. The first stage of the targeted physical therapy program: 
1. Maintaining the muscular strength in the muscles of the belts and the whole upper and lower limb;

2. Re-education of the control and coordination on the movements of the kinematic chain from the upper and lower extremities;

B. The second stage of the targeted physiotherapy:

1. Re-educate the projection of the centerline of the weight, with the improvement of balance and stability;

2. The improvement of the respiratory capacity;

C. The third stage of the physiotherapy program outcomes was set to:

1. Maintain effort capacity within medium limits, allowing ADLs, transfers and walking for short periods.

2. Extending the time duration of ambulance capacity The physical therapy program, in addition to the classical techniques used in muscular dystrophies, included neuro proprioceptive facilitation techniques which were correlated with Kabat diagonals. Initially, the objectives and types of exercises were centralized in a general treatment protocol. The physiotherapy exercise protocol was composed of exercises and technique items which were individualised by the functional evaluation of each patient.

For the upper extremity: assisted, self-passive or active analytical exercises, along the whole range of motion, removing the action of gravity or against the gravity (on each joint movement). Global exercises for the upper extremity, involving functional movements for ADLs and muscle strength. Kabat diagonals for Upper Limb and for shoulders. Occupational Therapy activities, Grasp and grip exercises and dexterity training for hand movements.

For the lower extremity: assisted, self-passive or active analytical exercises, along the whole range of motion, removing the action of gravity or against the gravity (on each joint movement). Global exercises for the upper extremity, involving functional movements for ADLs and muscle strength. Kabat diagonals for Lower Limb and for hips.

Respiratory training: Increase the respiratory capacity by training diaphragmatic breathing and increasing the diameter of the chest in inspiration. Posture to facilitate bronchial drainage Cardiovascular training involved ADL workout, walking on short distances, stairs climbing.
To promote the walking capacity and ambulance, exercises of stability, balance, walking between parallel bars, and walking over obstacles were performed.

After performing functional assessments, the kinetic program was adapted, using types of exercises according to the patient's needs and capacity, each task being oriented to increase functional activity. $[12,13,14]$.

For the statistical analysis we used the Microsoft Excel statistical functions. $T$ test was used to measure the score differences before and after physiotherapy interventions. The cut-off value for statistical significance was set to 0.5 .

\section{Results}

The distribution of the neuromuscular forms of muscle dystrophy we studied included $50 \%$ the myotonic form, $12 \%$ the limb-girdle form, and in equal percents - $19 \%$ the Duchene form and Facioscapulohumeral form.

The results for the range of motion assessment, muscle manual testing and functional assessment scales are presented in tables I,II,III.

Table II. T-Test results and statistical analysis for the range of motion initial and final assessment

\begin{tabular}{lcccc}
\hline Joint & Mean 1 & Mean 2 & $\begin{array}{c}\text { Std } \\
\text { Dev }\end{array}$ & T test \\
\hline Left Shoulder & 36.05 & 41.60 & 3.92 & 0.014 \\
\hline Right Shoulder & 36.99 & 41.75 & 3.36 & 0.021 \\
\hline $\begin{array}{l}\text { Left elbow and } \\
\text { forearm }\end{array}$ & 63.87 & 71.17 & 5.16 & 0.007 \\
\hline $\begin{array}{l}\text { Right elbow } \\
\text { and forearm }\end{array}$ & 64.06 & 71.42 & 5.20 & 0.009 \\
\hline Left hip & 14.78 & 17.15 & 1.67 & 0.004 \\
\hline Right Hip & 15.05 & 17.18 & 1.50 & 0.005 \\
\hline Left Knee & 71.30 & 74.60 & 1.78 & 0.045 \\
\hline Right Knee & 71.06 & 74.06 & 2.01 & 0.026 \\
\hline $\begin{array}{l}\text { Left ankle and } \\
\text { foot }\end{array}$ & 5.17 & 6.27 & 0.77 & 0.047 \\
\hline $\begin{array}{l}\text { Right ankle } \\
\text { and foot }\end{array}$ & 5.07 & 6.17 & 0.77 & 0.047 \\
\hline
\end{tabular}

Table III. T-Test results and statistical analysis for the muscle manual initial and final testing 


\begin{tabular}{lcccc}
\hline Muscle strength & $\begin{array}{l}\text { Mean } \\
1\end{array}$ & Mean 2 & $\begin{array}{l}\text { Std } \\
\text { Dev }\end{array}$ & T test \\
\hline Left Shoulder & 2.40 & 2.65 & 0.17 & 0.001 \\
\hline Right Shoulder & 2.42 & 2.66 & 0.16 & 0.001 \\
\hline $\begin{array}{l}\text { Left elbow and } \\
\text { forearm }\end{array}$ & 3.05 & 3.34 & 0.20 & 0.001 \\
\hline $\begin{array}{l}\text { Right elbow and } \\
\text { forearm }\end{array}$ & 3.11 & 3.36 & 0.17 & 0.001 \\
\hline Left hip & 2.49 & 2.65 & 0.11 & 0.001 \\
\hline Right Hip & 2.52 & 2.65 & 0.09 & 0.001 \\
\hline Left Knee & 2.77 & 2.92 & 0.13 & 0.001 \\
\hline Right Knee & 2.78 & 2.92 & 0.11 & 0.001 \\
\hline $\begin{array}{l}\text { Left ankle and } \\
\text { foot }\end{array}$ & 2.34 & 2.44 & 0.06 & 0.051 \\
\hline $\begin{array}{l}\text { Right ankle and } \\
\text { foot }\end{array}$ & 2.35 & 2.44 & 0.06 & 0.050 \\
\hline
\end{tabular}

Table IV. T-Test results and statistical analysis for the functional initial and final scale assessments

\begin{tabular}{lllll} 
Assessment & Mean 1 & Mean 2 & $\begin{array}{l}\text { Std } \\
\text { Dev }\end{array}$ & T test \\
\hline Brooke scale & 3.43 & 3.81 & 0.26 & 0.004 \\
\hline Vignos scale & 4.75 & 5.43 & 0.48 & 0.001 \\
\hline Barthel & 55.93 & 63.124 & 5.08 & 0.001 \\
\hline ADL score & 5.06 & 5.75 & 0.48 & 0.001 \\
\hline $\begin{array}{l}\text { Muscular } \\
\text { Dystrophy }\end{array}$ & $26.69 \%$ & $34.88 \%$ & 0.05 & 0.030 \\
\hline
\end{tabular}

On the Brooke Scale, 37, 50\% of the patients had a favourable evolution on the Brooke Scale.

In the group of 16 patients, it was found that $31.25 \%$ of the patients had a steady evolution on the Vignos Scale, while $68.75 \%$ of the patients had progressed on the Vignos Scale.

For a better understanding regarding the patients' evolution we graphically presented the evolution on the ADL and Barthel scales.

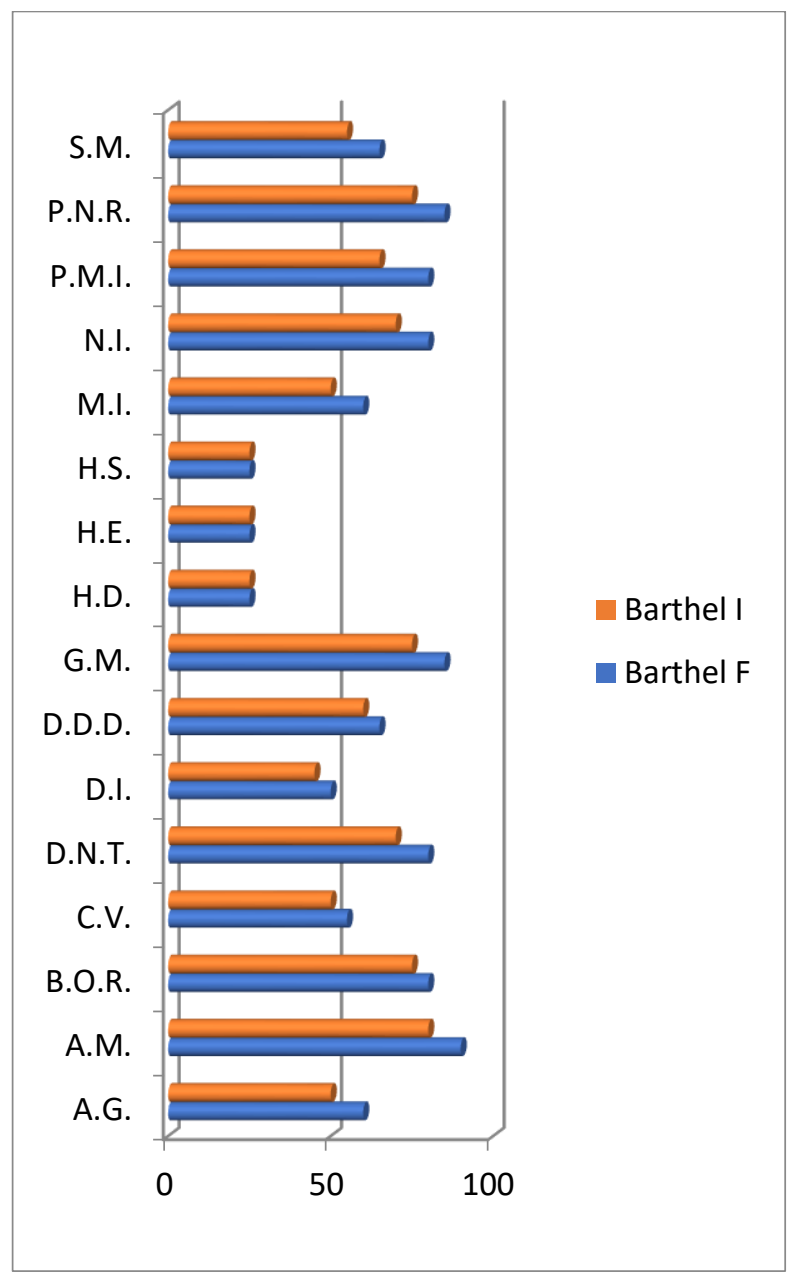

Figure 1 Barthel scale results at the first and last assessment

Following the final evaluation it was found that: $37.5 \%$ of the patients obtained a score of $<60$ on the Barthel Scale, $18.75 \%$ obtained a score of $60-75$, $43.75 \%$ obtained a score of $75-95$ on the Barthel Scale, and no patient achieved a score of $95-100$ (Figure 1). 


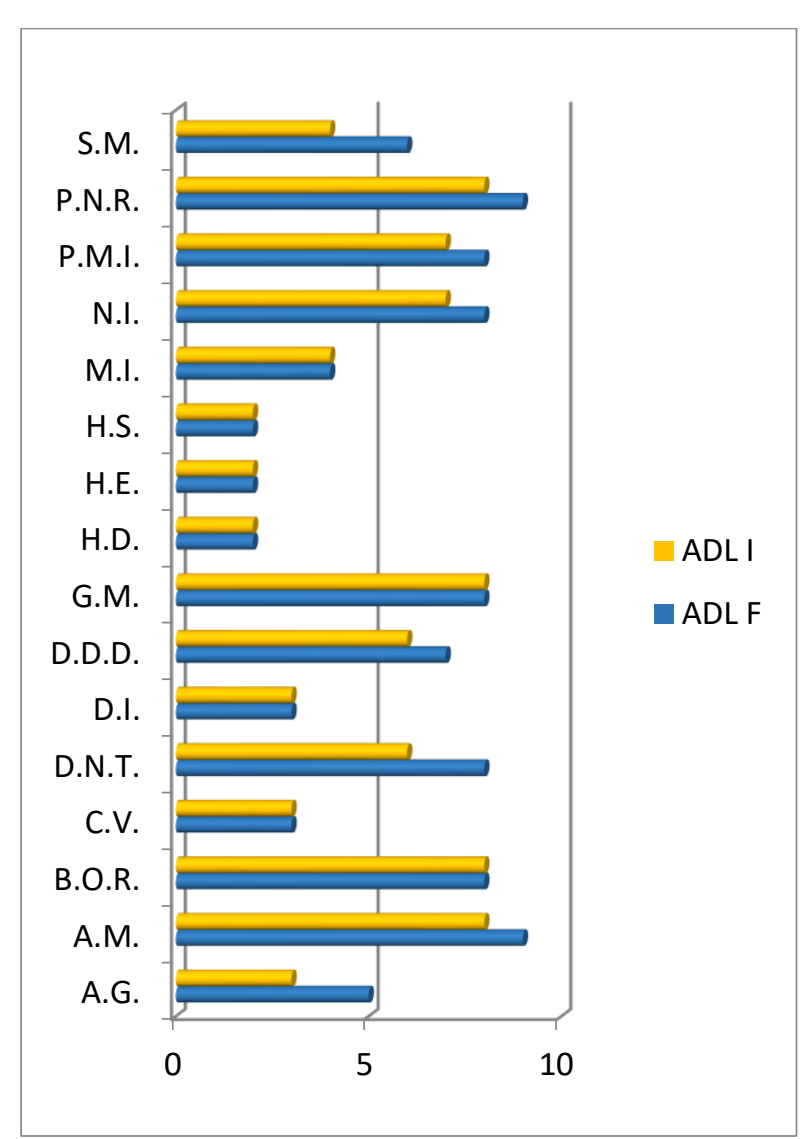

Figure 2. The ADL scale results at the first and last assessment

On the ADL scale, of the total group of patients, $50 \%$ did not change their score, $31.25 \%$ of the patients improved their score, but not the degree of dependence, and $18.75 \%$ of the patients improved their score as well as the degree of dependence (Figure 2).

In the case of the ADL assessment, as well as in the Barthel scale evaluations, significant improvements were observed, especially in the patients who had a lower degree of disability. Therefore, new challenges occur in the physiotherapy rehabilitation of muscular dystrophy.

Following the evaluation of the group of patients using the Scoring of Muscular Dystrophy and following the application of the recovery program it was found that the patients had an improvement in the functional percentage within the three evaluated domains.

- The mobility domain: at the first evaluation, the average functional percentage was of $28.08 \%$, the second evaluation was $29.93 \%$, and the three functional percentages of the evaluation increased to $35.21 \%$

\section{Discussion}

Based on the results of the evaluations and the implementation of the physical therapy program, the treatment applied to the group of patients with progressive muscular dystrophy had a positive effect, with a steady evolution, and even a slight improvement in some patients. Previous literature confirms our findings, although new modalities of muscle strength performance are developing, using different types of electrical stimulation, therefore new challenges occur in the physiotherapy rehabilitation of muscular dystrophy [15].

Following the application of the physiotherapy program and after the assessment of the patients, at the level of the muscular activity, a slight evolution was recorded. By gaining muscular strength, the joint has a good stability and coordination is improved. Most of the patients had a steady evolution or even a slight improvement of the muscular strength [16].

The active range of motion exercises also improved the amplitude of motion, increasing joint mobility and improving the capacity of active movement in the upper and lower extremities, and helped preventing muscle atrophy [17].

Patients with the Duchenne pathology, who are in a state of marked development of the disease, had a less notable evolution, but the individualised recovery program has succeeded in slowing the progression of the condition and maintaining the current state. It is known that the musculature level of functionality shows the debilitating level of dystrophies, and therefore, the results of our research strengthen the earlier findings and underline the importance of movement and muscle strength. [18]

In muscular dystrophy, physical training exercises have an impact both on muscle strength and on the cardio-respiratory capacity [19]. The impact of the physical therapy program is contingent on the patient's level of disability and the individualisation of the therapy program is essential for the suitable prevention of functional deterioration

\section{Conclusions}

Since muscular dystrophy is a progressive disorder, the recovery program and other treatments 
administered can only slow the progression of the disorder.

Patients in a more advanced stage of the disease had a steady evolution, while patients in a less developed stage experienced a slight improvement in their functional and independence status.

The associated pathologies present in some patients affected the recovery program, influencing its intensity, number of repetitions and degree of loading, depending on the associated pathology.

The individualisation of the recovery program according to the particularities and needs of each patient is very important for achieving the expected results.

The recovery of patients with progressive muscular dystrophy is a continuous struggle due to the progressive nature of this disorder. Besides the exercises applied by the physical therapist during hospital admission, the patient must follow the instructions given by the physiotherapist and physician after discharge.

1. Malak R., Kostiukow A., Krawczyk-Wasielewska A., Mojs E., Samborski W. (2015). Delays in Motor Development in Children with Down Syndrome, Medical Science Monitor: International Medical Journal of Experimental and Clinical Research, 21, 1904-1910.

\section{References}

1. Emery A.E.H. (2008). Muscular Dystrophy: The facts, Oxford University Press, Oxford, 3-15.

2. Stone K., Tester C., Blakeney J., Howarth A., Traynor N., McCutcheon M., Johnston R. (2007). Occupational Therapy and Duchenne muscular dystrophy, Wiley - 1 edition, 23-34.

3. Theadom A., Rodrigues M., Roxburgh R., Balalla S., Higgins C., Bhattacharjee R., Jones K., Krishnamurthi R., Feigin V. (2014). Prevalence of Muscular Dystrophies: A Systematic Literature Review, Neuroepidemiology, 43,259-268.

4. Ortez C., Natera de Benito D., Carrera García L., Expósito J., Nolasco G., Nascimento A. (2019). Advances in the treatment of Duchenne muscular dystrophy, Medicina (B Aires), 79 Suppl 3, 77-81.

5. Scutelnicu D. (2007). Neurologie curs, Editura Mirton, Timisoara, 55-122

6. Tawill R. (2008). Facioscapulohumeral Muscular Dystrophy, Neurotherapeutics5(4), 601-6.
7. Guglieri M., Straub V., Bushby, K., Lochmüller H. (2008). Limb-girdle muscular dystrophies, Current Opinion in Neurology, 21(5), 576-584.

8. Koenig M., Beggs A.H., Moyer M., Scherpf S., Heindrich K., Bettecken T. et al. (1989). The molecular basis for Duchenne versus Becker muscular dystrophy: Correlation of severity with type of deletion, The American Journal of Human Genetics,45(4), 498-506.

9. Mahjneh I., Bushby K., Pizzi A., Bashir R., Marconi G. (1996). Limb-girdle muscular dystrophy: a follow-up study of 79 patients, Acta Neurologica Scandinavica, 94 (3), 177-189.

10. Chisari C., Bertolucci F., Dalise S., Rossi B. (2013). Chronic muscle stimulation improves muscle function and reverts the abnormal surface EMG pattern in Myotonic Dystrophy: a pilot study, Journal of Neuroengineering and Rehabilitation, 10,94 .

11. Malhotra S.B., Hart K.A., Klamut N.S.T., Bodrug S.E. (1988). Frame-Shift Deletions in Patients with Duchenne and Becher Muscular Dystrophy, Science, 242(4879), 755-759.

12. Grange R.W., Call J.A. (2007). Recommendations to define exercise prescription for Duchenne muscular dystrophy, Exercise and Sport Sciences Reviews, 35(1), 12-7.

13. Jansen M., Van Alfen N., Geurts A.C.H., De Groot I. J.M. (2013). Assisted bicycle training delays functional deterioration in boys with Duchenne muscular dystrophy: The randomized controlled trial "No use in disue”, Neurorehabilitation and Neural Repair, 27(9), 816-827.

14. Lovering, R.M., Porter, N.C., Bloch, R.J. (2005)The Muscular Dystrophies: From Genes to Therapies. Journal of the American Physical Therapy Association, 85(12):1372-1388.

15. Kilinç M., Yildirim S. A., Tan E. (2015). The effects of electrical stimulation and exercise therapy in patients with limb girdle muscular dystrophy. A controlled clinical trial, Neurosciences, 20(3), 259-266.

16. Gianola S., Pecoraro V., Lambiase S., Gatti R., Banfi G., Moja L. (2013). Efficacy of muscle exercise in patients with muscular dystrophy: a systematic review showing a missed opportunity to improve outcomes, PloS one, 8(6), e65414.

17. Connolly A. M., Malkus E. C., Mendell J. R., Flanigan K.M., Miller J. P., Schierbecker J. R., et al., 
MDA DMD Clinical Research Network (2015). Outcome reliability in non-ambulatory boys/men with Duchenne muscular dystrophy, Muscle \& Nerve, 51(4), 522-532.

18. Bakker J.P.J., de Groot I.J.M., Beelen A., Lankhorst G.J. (2002). Predictive Factors of Cessation of Ambulation in Patients with Duchenne Muscular
Dystrophy, American Journal of Physical Medicine \& Rehabilitation, 81(12),906-912.

19. Jansen M., de Groot I.J., van Alfen N. et al. (2010). Physical training in boys with Duchenne Muscular Dystrophy: the protocol of the No Use is Disuse study, BMC Pediatrics, 10, 55. 